Sharif University of Technology
Scientia Iranica
TCIENTIA
I RAN ICA
http://scientiairanica.sharif.edu

\title{
Performance of CFRP-confined pultruded GFRP-concrete composite columns subjected to cyclic and monotonic compressive loading
}

\author{
M. Ishaqian and A. Keramati* \\ Department of Civil Engineering, Amirkabir University of Technology, 424 Hafez Ave, Tehran, P.O. Box 15875-4413, Iran.
}

Received 22 February 2016; received in revised form 6 June 2016; accepted 28 April 2020

\author{
KEYWORDS \\ Column; \\ Composite; \\ Concrete; \\ CFRP; \\ Pultrusion; \\ Compression; \\ Cyclic.
}

\begin{abstract}
A new composite column composed of pultrusion, concrete, and FiberReinforced Polymer (FRP) is presented in this paper. The confinement and composite action between the constituent materials result in the enhanced compressive strength and ductility of the proposed composite columns, compared to traditionally reinforced concrete columns. Compared to other materials, advantages of FRP products include light weight, high specific strength, corrosion resistance, and low maintenance cost. This research showed that I-shaped pultruded Glass Fiber-Reinforced Polymer (GFRP) could satisfactorily improve the structural performance of concrete columns. The effectiveness of discrete and continuous Carbon Fiber-Reinforced Polymer (CFRP) wrapping arrangements for pultrusion-concrete composite short columns subjected to axial compressive loading is assessed in this study. The experimental program is composed of one series of composite columns with discrete wrapping arrangements and one series of fully wrapped composite columns. A numerical model was developed to predict the behavior of the FRP-confined composite columns subjected to axial compressive loading. The damage mechanisms of the columns wrapped by the composite layers are strongly dependent on the chosen materials. The results of finite element models are compared with the data obtained from the conducted experimental program, which showed good agreement between the results and the experimental data.

(C) 2020 Sharif University of Technology. All rights reserved.
\end{abstract}

\section{Introduction}

Fiber Reinforced Polymer (FRP) materials are widely utilized in the construction of structural members due to their high strength-to-weight ratio and corrosion resistance. In strengthening Reinforced Concrete (RC) columns, FRPs are primarily used as an external jacket to provide confinement to the concrete core [1-3]. More

\footnotetext{
*. Corresponding author.

E-mail addresses: M.Ishaqian@aut.ac.ir (M. Ishaqian); keramati@aut.ac.ir (A.Keramati)
}

recently, the focus has turned to the application of FRP composites for developing new high-performance composite structural systems. Being one of the most promising of these structural systems, Concrete-Filled FRP Tubes (CFFTs) have been investigated extensively [4-15]. Typically, the scope of the related studies has been limited to monotonic compressive loading, except few ones which have explored the effect of the cyclic loading on the behavior of FRP-confined concrete elements. Following from the research on CFFTs, a new type of composite system, originally proposed by Teng et al. [16], consists of an inner steel tube, an outer FRP tube, and concrete filling in between two tubes (and if preferred, inside the steel tube), and 
it has recently received significant research attention. These FRP-concrete-steel double-skin tubular columns and beams have improved structural performance and reduced the cost of construction and structural maintenance under axial compression [17-23] and cyclic lateral loading [24-27]. The structural properties of high-strength concrete over normal-strength concrete make it an attractive alternative for use in the construction of CFFTs. These studies have demonstrated the ability of the composite columns to exhibit highly ductile behavior under both concentric and seismic loading conditions [28-34]. It is well understood that the inherently brittle behavior of plain concrete can be improved with the addition of internal steel fibers to the wet concrete mix. The behavior of steel fiberreinforced high-strength concrete-filled FRP tubes has been widely studied over the past three decades [3540]. Several studies have been reported to date on the modeling of concrete compressive strength. To establish such an expression, the mix designs of various types of concrete in the database were carefully studied, and important parameters identified to have significant effect on the compressive strength of concrete were quantified [41-46]. In an effort to integrate the advantages of various construction materials, Karimi et al. [47] proposed a new composite column. The composite column consists of a steel section surrounded by a CFFT, which eliminates the need for lateral ties. In fact, wrapping concrete circular columns, fully or partially, with wet lay-up Carbon FiberReinforced Polymer (CFRP) sheets can significantly increase load-carrying and energy absorption capacities of these elements. In this study, the steel section is replaced by a pultruded I-section glass FRP, as shown in Figure 1(c). The effectiveness of the FRP confinement strategy depends on several parameters such as concrete strength, FRP percentage, geometric confinement arrangement, column aspect ratio, and area of existing pultruded I-section. Some properties of FRP layers such as low weight, high strength, and easy installation make these composites highly suitable for concrete confinement. Glass Fiber-Reinforced Polymer (GFRP) has been already well documented as a structural material. However, GFRP applications in current practices are still rare due to their lower strength than CFRP. To overcome such disadvantages, many authors have proposed a number of structural elements in which GFRP is combined with other structural materials $[48,49]$. Another application of combining a pultruded GFRP with concrete was proposed and tested [5052]. GFRP pultruded is commercially available and is mainly used to build walkways to be used in corrosive conditions. Adding a layer of concrete to the GFRP significantly increases the stiffness of the system, where GFRP functions as reinforcement for the concrete. The previous research on the strengthening of steel-concrete composite beams with FRPs showed that flexural load-bearing capacity and ductility of these composite beams increased significantly due to the application of FRPs [53]. In general, similitude law including geometric concept is the basis of performing small-scale model tests. However, due to the discrepancy between the small-scale model and prototype, experimental results obtained from small-scale models should be used carefully $[50,52,54,55]$.

In the present work, a Finite Element (FE) model for CFRP-confined composite concrete columns subjected to monotonic and cyclic loadings was proposed. The performance of the developed numerical model was compared with the results of experimental tests conducted on five composite column specimens confined to CFRP layers and subjected to monotonic and cyclic axial compressive loading. The Tsai-Wu three-dimensional interactive failure criterion was im-

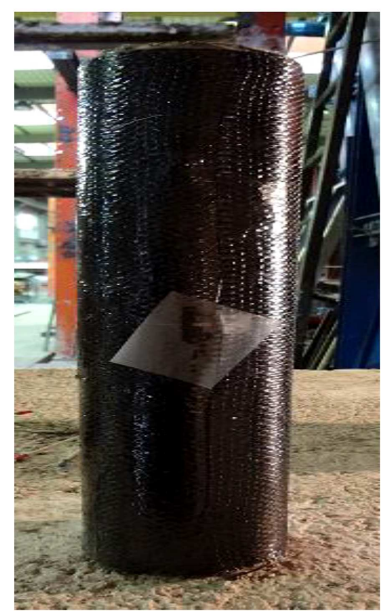

(a)

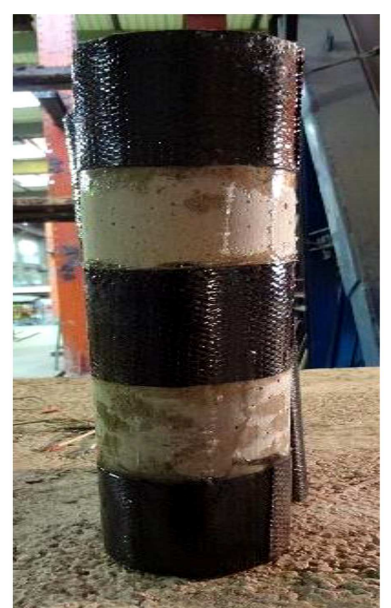

(b)

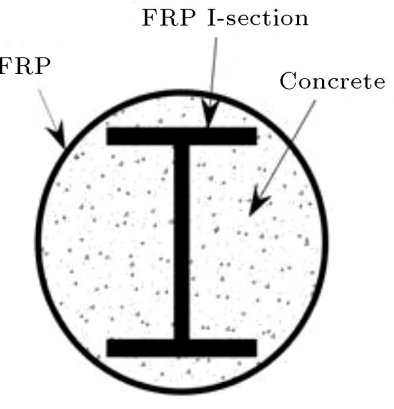

(c)

Figure 1. Photographs of the Carbon Fiber-Reinforced Polymer (CFRP) confinement arrangement for columns: (a) Fully confinement, (b) partially confinement, and (c) schematic view of the cross-section. 
plemented for composite columns in order to identify the failure mode. The present work deals with the most effective discrete confinement arrangements and compares their performance with those obtained from continuous confinement arrangements. In addition, the ultimate load capacity and the failure mechanism of the composite columns were investigated.

\section{Experimental program}

The experimental program consists of monotonic and cyclic axial compression tests, and test specimens are composed of two groups of concrete cylinders characterized by $108 \mathrm{~mm}$ diameter, $500 \mathrm{~mm}$ height, and encased structural pultruded I shape. A clear concrete cover of I-shaped GFRP was $29 \mathrm{~mm}$. The scope of the test program is shown in Table 1. A total of five concrete cylinders were tested to evaluate the effectiveness of full and partial CFRP confinement arrangements. The experimental program aimed to study the role of the following parameters in concrete confinement effectiveness: concrete strength class, stiffness and percentage of the wet lay-up CFRP layer, and width of the CFRP strip. The pultruded I shapes are characterized by an identical cross-section of $40 \mathrm{~mm}$ depth $\left(d_{s}\right), 60 \mathrm{~mm}$ flange breadth $\left(b_{f}\right)$, and web and flange thicknesses of $5 \mathrm{~mm}\left(t_{w}\right)$ and $\left(t_{f}\right)$, respectively. Each specimen of the first and second series is designated as CF-c/m (full CFRP confinement arrangement) and CP-c/m (partial CFRP confinement arrangement), respectively.
To distinguish between cyclic and monotonic tests, the letters $\mathrm{c}$ and $\mathrm{m}$ were attributed to the specimens submitted to cyclic and monotonic tests, respectively. Each series of direct compression tests was composed of two specimens, one of which was submitted to monotonic loading and the other to cyclic loading. Figure 1 shows the confinement arrangements adopted in this work. The strip width of a composite column was $100 \mathrm{~mm}$ and the number of strips along the depth of a cylinder was three. In Table 1, C represents a concrete specimen with encased structural pultruded I shape without any CFRP confinement arrangement.

\subsection{Material properties}

The GFRP pultruded I sections used in this study were manufactured by the pultrusion technique and the surface was evenly treated to enhance the bond characteristics. They are made of a continuous longitudinal glass-fiber strands bond with the thermosetting polyester resin. The mechanical properties of the used pultruded fiberglass are given in Table 2 according to manufacturer's data (Asia composites) obtained from standard tests. The concrete compressive strength was determined from tests on cylinders characterized by $300 \mathrm{~mm}$ height, $150 \mathrm{~mm}$ diameter, and an average compressive strength of $30 \mathrm{MPa}$. To prepare CFRPconfined specimens, the surfaces of original concrete cylinders were cleaned and completely dried before applying the epoxy. An epoxy system (SIKADUR 330) composed of resin and hardener (mixed in the

Table 1. Scope of the test program.

\begin{tabular}{|c|c|c|c|c|}
\hline Specimen type & $\begin{array}{l}\text { Specimen } \\
\text { ID }\end{array}$ & $\begin{array}{l}\text { Loading } \\
\text { type }\end{array}$ & $\begin{array}{c}\text { CFRP layer } \\
\text { thickness }(\mathrm{mm})\end{array}$ & $\begin{array}{c}\text { Pultruded shape } \\
d_{s} \times b_{f} \times t_{w} \times t_{f}(\mathrm{~mm})\end{array}$ \\
\hline Unconfined concrete cylinder & $\mathrm{C}$ & Monotonic & N.A. & $40 \times 60 \times 5 \times 5$ \\
\hline \multirow{2}{*}{ Full CFRP confinement arrangement } & $\mathrm{C}-\mathrm{m}$ & Monotonic & 0.4 & $40 \times 60 \times 5 \times 5$ \\
\hline & $\mathrm{C}-\mathrm{c}$ & Cyclic & 0.4 & $40 \times 60 \times 5 \times 5$ \\
\hline \multirow{2}{*}{ Partial CFRP confinement arrangement } & $\mathrm{CP}-\mathrm{m}$ & Monotonic & 0.4 & $40 \times 60 \times 5 \times 5$ \\
\hline & $\mathrm{CP}-\mathrm{c}$ & Cyclic & 0.4 & $40 \times 60 \times 5 \times 5$ \\
\hline
\end{tabular}

Table 2. Mechanical properties of the composite materials.

\begin{tabular}{cccc}
\hline Type of composite & CFRP layer & Pultruded fiberglass & Resin \\
\hline Tensile strength (MPa) & 894 & 547 & 33.8 \\
Elastic modulus (GPa) & 65.4 & 26 & 4.48 \\
Compressive strength (MPa) & 779 & 547 & 85.5 \\
Elastic modulus (GPa) & 67 & 17 & 2.69 \\
Shear strength (MPa) & 63 & 50 & 24.8 \\
Ultimate Tensile Strain (\%) & 1.4 & 2.5 & 1.2 \\
Poisson ratio in x-y plane & 0.22 & 0.25 & - \\
Poisson ratio in y-z plane & 0.3 & 0.32 & - \\
Poisson ratio in x-z plane & 0.22 & 0.25 & - \\
\hline
\end{tabular}


ratio of 4:1) was thoroughly hand mixed for at least 5 minutes. A thin layer of epoxy was applied to the original concrete cylinder. A fiber layer was then wrapped directly around the surface with an overlap along the circumferential direction equal to $1 / 3$ of the column perimeter $(100 \mathrm{~mm})$. After applying the fiber layer, the last layer of epoxy was applied to the surface of the wrapped cylinder. All specimens were wrapped at a 0 -degree orientation and were kept at room temperature for at least 21 days before testing for the epoxy system to cure. The mechanical properties of the CFRP layer (Sika Wrap Hex 230C) and resin used in the experimental program are presented in Table 2 according to manufacturer's data.

\subsection{Experimental setup and instrumentation}

The test setup of compressive loading for the column specimens is presented in Figure 2. The test specimens were simply supported by steel plates at two ends. The composite columns were tested using a compression test apparatus capable of applying $1000 \mathrm{kN}$ in Building and Housing Research Center (BHRC). The monotonic and cyclic compressive loads were applied by a hydraulic jack to the specimens through steel spreader plates. Columns were tested using an incremental loading procedure. The experiments were performed until the specimens failed. The level of load applied to the column specimens was continuously measured by means of a load cell. The load was kept constant at each load stage to allow for measurements and observations. During the composite columns test, the loaddisplacement relationship and the strain distribution of the CFRP wrappings and concrete were measured to study the mechanical behavior of these composite columns under cyclic and monotonic loading. Four axial and lateral strain gauges were installed at the centre point of the cylinders (Figure 2).

Four Linear Variable Displacement Transducers (LVDTs) were placed at the end of cylindrical specimens to measure the displacements of the steel loading plates (Figure 2). Moreover, to measure the axial deformation, four LVDTs were placed at the mid-height of the specimens.

This monitoring arrangement prevents the deformation of the equipment from being added to the values recorded by the LVDTs for the test specimens. All of the measurements were automatically recorded through a data logger. The composite specimens subjected to cyclic compressive load were tested under force control statically without a significant rate, according to the loading history (Figure 3) [51]. It should be noted that at the start of cyclic tests, the columns were under a compressive preloading of $5 \mathrm{kN}$. The specimens subjected to monotonic loading were tested under displacement-controlled loading statically without a significant rate.

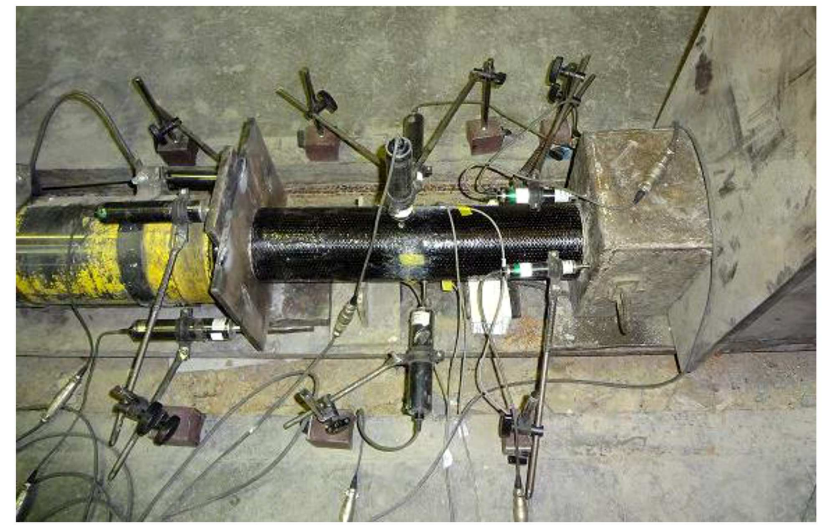

(a)

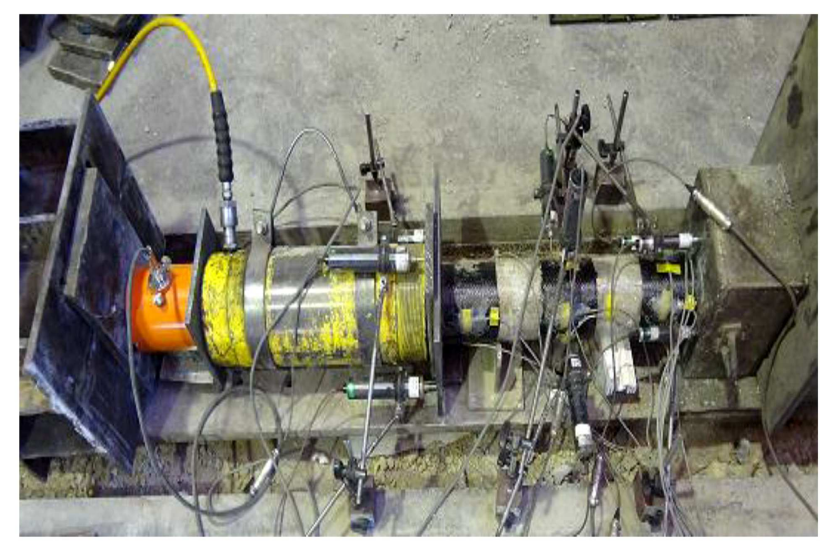

(b)

Figure 2. Photographs of experimental setup and instrumentation: (a) Fully wrapped columns and (b) partially wrapped columns.

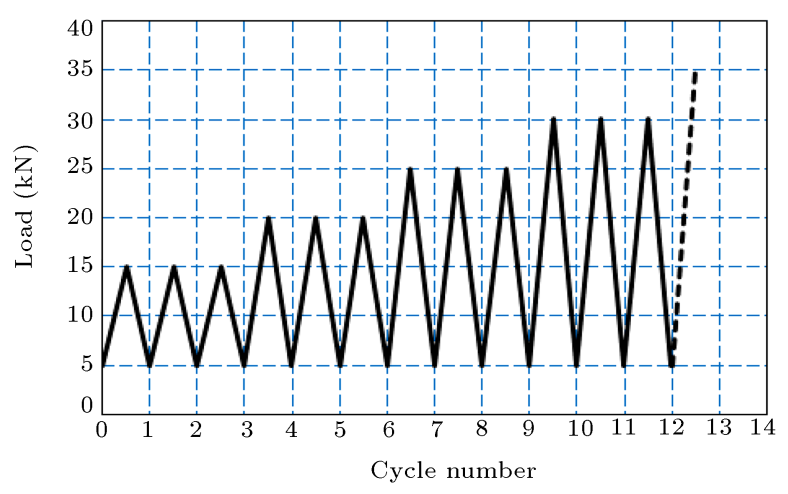

Figure 3. Cyclic loading configuration.

\section{Test results and analysis}

The test results are presented and the effects of the test parameters on the compressive behavior such as load-displacement relationship, stiffness, ductility, and failure modes are discussed in the following sections. Note that although CFRP-reinforced composite columns behaved essentially in an elastic brittle fashion after cracking up to the failure load, the results showed 
that both confinement methods significantly enhanced the load-carrying capacity and stiffness of composite columns.

\subsection{Load-deflection behavior}

The load-displacement responses of the fully and partially CFRP-confined (both series) specimens, unconfined specimen, and pultruded I-shaped specimen for both monotonic and cyclic tests are shown in Figure 4. The envelope curve of the cyclic tests follows approximately the curve of the monotonic test of the corresponding specimen. By comparing the results of specimens under cyclic loading, it can be concluded that full wrapping is more effective than the partial confinement arrangement. A similar tendency for the specimens subjected to monotonic loading was expected. The lower effectiveness of partial confinement systems can be justified by the accumulated damage in the unconfined concrete between strips. This effect is more pronounced in specimens subjected to cyclic loading since the concrete plastic strain increases in the subsequent cycles of the same load amplitude

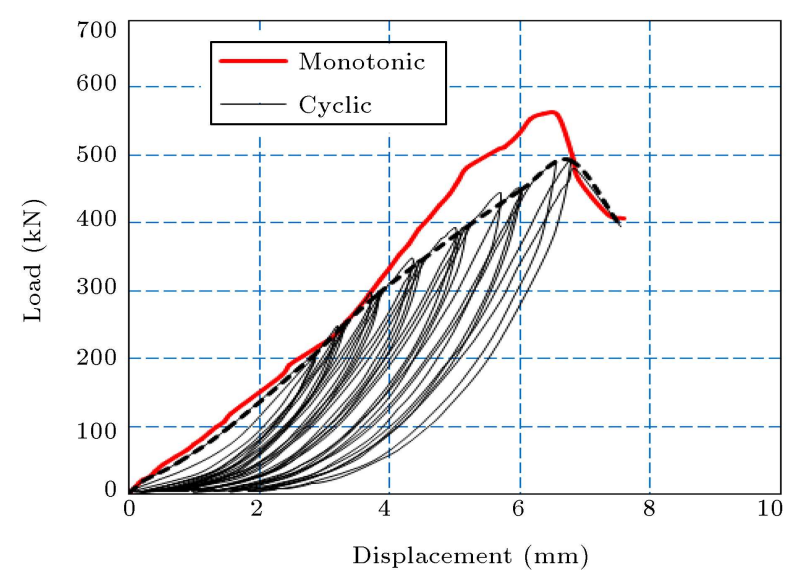

(a)

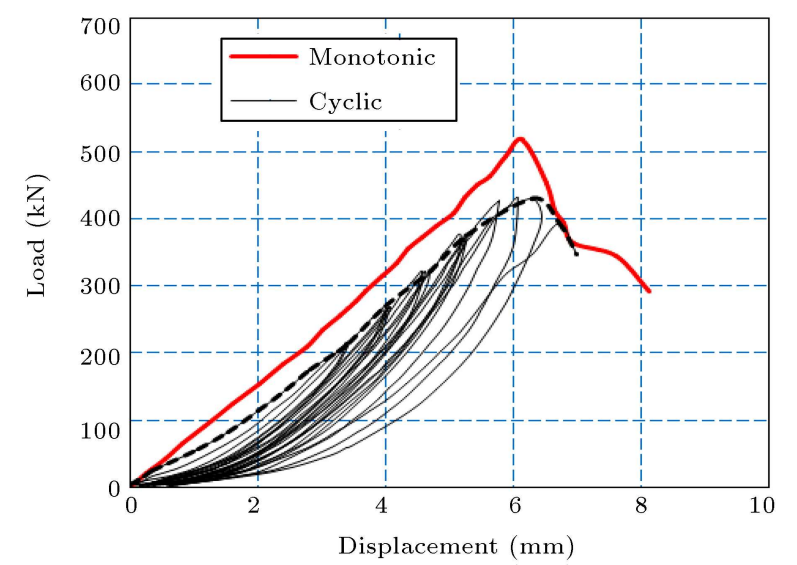

(b)

Figure 4. Load-deflection responses based on monotonic and cyclic tests: (a) Fully confined and (b) partially confined.
(Figure 4). As expected, since specimens CP had a higher reinforcement ratio, they achieved more favorable deformability than specimens CF. The strength and stiffness of specimens CF-m/c were greater than those of specimens CP-m/c. The total applied load of the pultruded I-shaped column increased linearly with deflection until reaching $95 \mathrm{kN}$ where the failure of compression flange started. The strength and stiffness of columns increase by using FRP having the same pultruded fiberglass I shapes. Furthermore, with increase in the ratio of CFRP from $60 \%(\mathrm{CP}-\mathrm{m} / \mathrm{c})$ to $100 \%$ $(\mathrm{CF}-\mathrm{m} / \mathrm{c})$, the ultimate deflection, the load-carrying capacity, and the displacement ductility increased. In the successive series of load cycles, a tendency for the reducing stiffness of both unloading and reloading branches is observed in all tested specimens. The reduced level of the stiffness of these branches diminished with increase in the specimen axial deformation. The stiffness of the unloading and reloading branches seems to approach a constant value.

In the case of fully wrapped specimens, this value is almost the same for both of the unloading and reloading branches, while in the case of specimens with a partial confinement arrangement, the stiffness of unloading branches is higher than that of reloading branches. This can be justified by the dilation of the unconfined concrete in between CFRP strips.

\subsection{Comparison between fully and partially CFRP layers}

The load-displacement responses of fully and partially wrapped specimens show nonlinear behaviors throughout the test and strain softening behavior after peak stress. Failure of the composite columns was diagnosed with a reduction in the load level. Therefore, the ultimate strain was used as a comparative parameter between these two confinement methods and, also, it can be determined from the load-strain diagram. From the analysis of the configuration of the loaddisplacement unloading and reloading branches of each load cycle, it can be verified that the unloading branch is eminently nonlinear, while the reloading branch is formed by nonlinear segments of reduced amplitude at its extremities, connected by a linear part. Furthermore, the partial wrapping arrangement assured a high level of deformability at specimen failure and prevented the rupture modes from being as violent as those of the fully wrapped specimens, since part of the internal energy gradually dissipated due to the compression strain-softening behavior of the concrete in between CFRP strips. Increase in the concrete axial strain can be justified by concrete dilation, mainly in the zones between CFRP strips, while increase in CFRP tensile strain can be justified by increase in concrete plastic strain in subsequent load cycles. In fact, the recovered strain in the unloading branch of each cycle is only part 
Table 3. Experimental and numerical maximum stresses, failure load, deflections, ductility, experimental strain (axial and circumferential), and modes of failure of the tested specimens.

\begin{tabular}{|c|c|c|c|c|c|c|c|c|c|c|c|c|c|c|}
\hline \multirow[t]{2}{*}{ Specimen } & \multirow[t]{2}{*}{$\begin{array}{l}\text { Loading } \\
\text { type }\end{array}$} & \multicolumn{2}{|c|}{$\begin{array}{c}\text { Maximum } \\
\text { stress } \\
\text { (MPa) }\end{array}$} & \multicolumn{2}{|c|}{$\begin{array}{c}\text { Failure } \\
\text { stress } \\
(\mathrm{MPa})\end{array}$} & \multicolumn{2}{|c|}{$\begin{array}{c}\text { Elastic } \\
\text { strain } \\
(\%)\end{array}$} & \multicolumn{2}{|c|}{$\begin{array}{c}\text { Failure } \\
\text { strain } \\
(\%)\end{array}$} & \multicolumn{2}{|c|}{$\begin{array}{l}\text { Ductility } \\
\text { index }\end{array}$} & \multicolumn{2}{|c|}{$\begin{array}{c}\text { Ultimate } \\
\text { strain } \\
(\%)\end{array}$} & \multirow[t]{2}{*}{ Mode of failure } \\
\hline & & Exp. & Num. ${ }^{a}$ & Exp. & Num. & Exp. & Num. & Exp. & Num. & Exp. & Num. & Axial & Circum. $^{b}$ & \\
\hline $\mathrm{C}$ & Monotonic & 38.5 & 39.3 & 32.0 & 29.6 & 0.62 & 0.68 & 1.1 & 6.0 & 1.77 & 1.76 & 1.44 & 1.51 & Concrete crushing \\
\hline \multirow[t]{2}{*}{$\mathrm{CF}$} & Monotonic & 61.2 & 60.9 & 42.5 & 43.7 & 0.74 & 0.76 & 1.52 & 1.6 & 2.05 & 2.1 & 0.87 & 0.34 & CFRP rupture \\
\hline & Cyclic & 54.2 & 53.4 & 43.1 & 42.1 & 0.66 & 0.84 & 1.72 & 1.9 & 2.61 & 2.26 & 0.74 & 0.50 & $\begin{array}{c}\text { Pultruded failure } \\
\text { before CFRP rupture }\end{array}$ \\
\hline \multirow[t]{2}{*}{$\mathrm{CP}$} & Monotonic & 56.5 & 55.1 & 37.6 & 37.2 & 0.76 & 0.78 & 1.52 & 1.6 & 2.0 & 2.05 & 1.37 & 0.81 & $\begin{array}{l}\text { Debonding between } \\
\text { CFRP and concrete }\end{array}$ \\
\hline & Cyclic & 47.0 & 47.3 & 37.9 & 34.3 & 0.68 & 0.74 & 1.4 & 1.4 & 2.06 & 1.9 & 0.53 & 0.33 & Concrete crushing \\
\hline
\end{tabular}

of the strain increment that occurs in the reloading branch of the previous cycle, which means that an increment in the CFRP strain in subsequent load cycles is observed. The shape of the unloading and reloading branches appears to be similar in both partially and fully confined specimens. It can be seen that upon failure, the GFRP strain was lower than its ultimate value which can be seen numerically. Although the partial wrapping arrangements were not as effective in terms of load-carrying capacity as the full wrapping arrangements, they provided a significant increase in the specimen load-carrying capacity. To evaluate the ductility of specimens, a ductility index was defined as the ratio of the post-peak displacement corresponding to failure load to the displacement corresponding to the elastic load [56-59]. The larger the ductility index, the better the seismic performance of the column. The ultimate and elastic displacements at column midspan are listed in Table 3 . Note that although FRP columns behaved essentially in an elastic brittle fashion after cracking up to failure, the ductility factor was still evaluated by the method described above for comparison purposes.

\subsection{Failure mode}

A summary of the test results is presented in Table 3 . The experimental and numerical ultimate stresses, displacement ductility, maximum stress, maximum experimental modes (axial and circumferential directions of the CFRP layer), and failure modes of all the composite columns specimens are included to the table. All the CFRP-wrapped cylinders failed by the rupture of the FRP jacket due to the hoop tension. The CFRPconfined specimens failed suddenly and explosively and were only preceded by some snapping sounds. None of the specimens failed at the overlap location of the jacket, which confirmed the adequate stress transfer over the splice. The control specimen, C (unconfined), failed by concrete crushing before pultrusion I-shaped rupture. At a low loading level, all specimens exhibited a similar cracking behavior. The cracks induced by compressive load appeared first in the specimen height at approximately $15 \%$ of their measured peak loading. The load-carrying capacity was partially recovered in the case of some specimens with further incremental deflection. Sounds coming out of the fracture of the CFRP layer and I-shaped GFRP became audible for the large deflections and, eventually, the rupture of the FRP triggered the final failure of specimens. The failure of the composite columns, $\mathrm{CP}-\mathrm{c} / \mathrm{m}$, was brittle and the corresponding photos of failure conditions are shown in Figure 5. It can be observed that debonding occurs between the composite reinforcement and the concrete surface in the specimen CP-m and that the concrete in the specimen CP-c crushes. Furthermore, the end-height deflections of the column specimens $\mathrm{CP}-\mathrm{c} / \mathrm{m}$ and $\mathrm{CF}-\mathrm{m} / \mathrm{c}$ upon failure ranged between 7 and $8 \mathrm{~mm}$. The ultimate deformability of the column specimens occurred due to the amount of CFRP confinement. This is attributed to the final failure modes resulting from the fracture of FRP and concrete crushing. Moreover, for column specimens $\mathrm{CF}-\mathrm{c} / \mathrm{m}$ with full confinement arrangement, their failure arose from the sudden rupture of CFRP confinement and no compression failure of concrete occurred. In addition, the pultruded fiberglass failed in the specimen CF-c. The corresponding final failure for these specimens is shown in Figure 5. Different failure modes between the composite column specimens $\mathrm{CF}-\mathrm{c} / \mathrm{m}$ and $\mathrm{CP}-\mathrm{c} / \mathrm{m}$ showed that partial CFRP confinement arrangement changed the failure mode from a non-ductile manner to a ductile one. In addition, the final failure of the I-shaped GFRP in all specimens again confirmed that force transfer was sufficient to develop the full tensile capacity of CFRP wrapping.

\section{Simulation analyses}

In order to carry out a comparative investigation into the effect of full and partial confinement of pultrusion- 


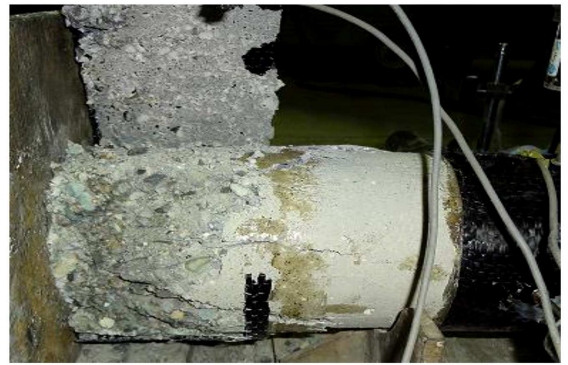

(a) Specimen CP-m

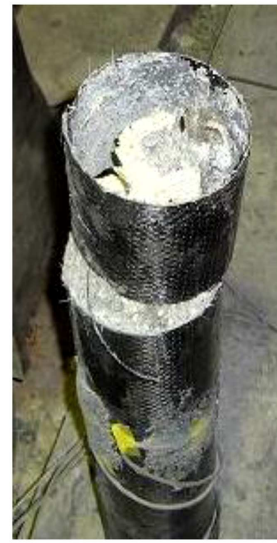

(c) Specimen CF-m

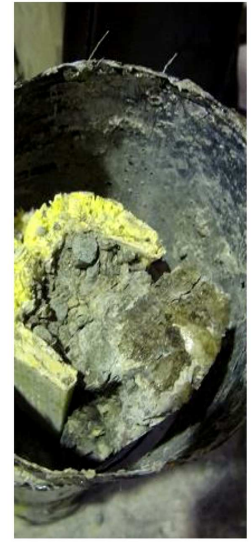

(d) Specimen $\mathrm{CF}$-c

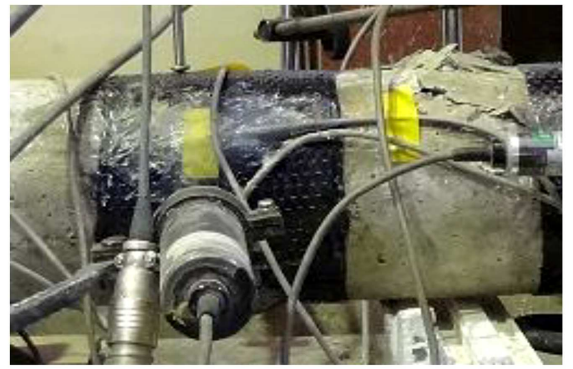

(b) Specimen CP-c
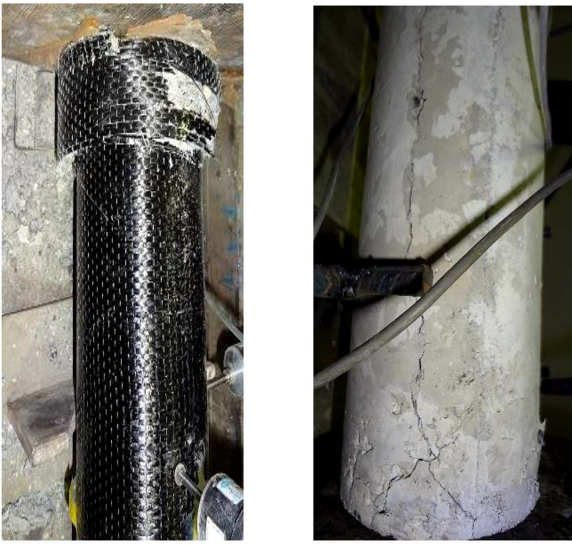

(e) Specimen C

Figure 5. Photographs of the tested specimens after failure.

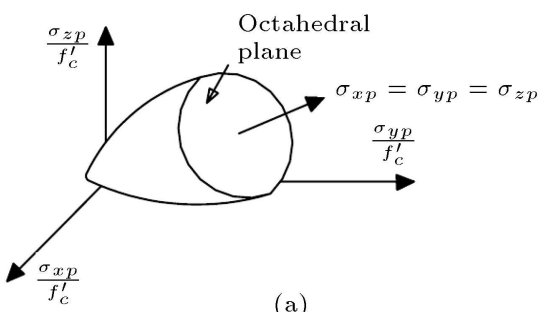

(a)

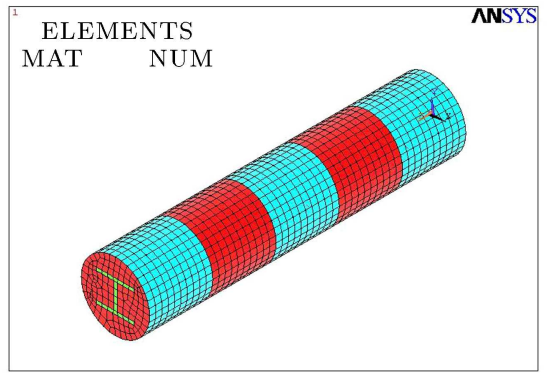

(c)

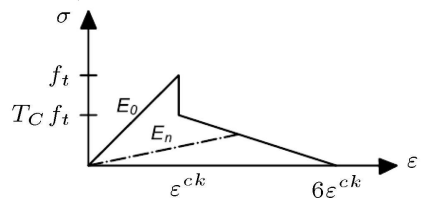

(b)

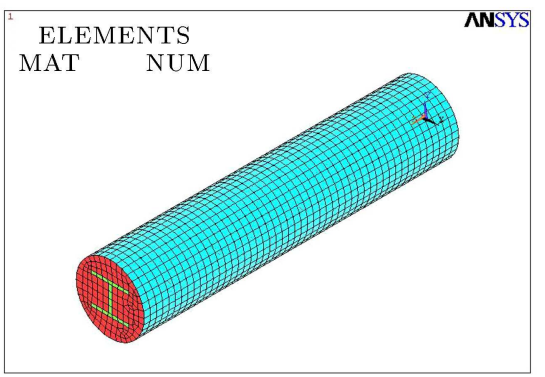

(d)

Figure 6. Finite Element (FE) modeling, constituents of composite column: (a) Failure envelop of concrete, (b) smeared crack stiffness, (c) partially confined column, and (d) fully confined column.

concrete composite columns under different conditions, nonlinear FE analyses have been undertaken using the FEM code ANSYS [60]. The following summarizes the numerical approach.

\subsection{Type of the FEs used in the modeling}

The applied FE composite column model is shown in Figure 6. Three-dimensional solid element (solid46) was used to model the pultruded fiberglass I-shaped section. Solid46 was used for the 3D modeling of solid structures. The element, solid46, is defined by eight nodes, each having three degrees of freedom. The element has plasticity, creep, swelling, stress stiffening, large deflection, and large strain capabilities. The CFRP layer was modeled using elastic shell elements (SHELL181). This element consists of four nodes and 
has six degrees of freedom per node (three translational and three rotational). The constitutive behavior of these FRP elements was modeled using orthotropic properties, as shown in Table 2. The Tsai-Wu failure criterion was adopted to determine the failure of the composites. An assumption commonly made in FRP modeling is that FRP is a linear elastic material until it reaches its tensile strength and has orthotropic material properties; of note, even when very large pressure load such as blast load is applied, it is commonly assumed that FRP is an order to consider the directional characteristics of FRP and that it has to be modeled as an orthotropic material. If this is the case, then a linear elastic orthotropic material model has at least two symmetrical orthogonal planes. Three-dimensional solid element (solid65) was selected to model the concrete core. Solid65 is used for the 3D modeling of solids with or without reinforcing bars. The element is capable of cracking, crushing in compression, plastic deformation, and creep cracking in tension. The most important aspect of this element is the treatment of material nonlinear properties. The Willam and Warnke approach was adopted to represent the behavior of the concrete $[60,61]$. The failure envelope of the concrete model is shown in Figure 6(a). Solid65 is able to simulate the crushing and cracking of concrete. The fundamental philosophy of cracking is that a concrete element cracks when the principal stress on that element exceeds a critical limit such as the modulus of rupture $\left(f_{t}\right)$ in tension (Figure 6(b)). The effect of tensile stress relaxation was taken into account $(T c=0.6$ in Figure $6(\mathrm{~b}))$. The direction of the cracks is, therefore, perpendicular to the principal stress direction. Once cracking occurs in a specific direction of the element, the corresponding stiffness (En) is reduced to zero so that the contribution of the cracked element to the behavior of the structure is none, as shown in Figure 5(b). The concrete material is initially isotropic, whereas it becomes orthotropic once cracks are formed. The crushing model has a similar philosophy to the cracking model such that the failure of a concrete element at an integration point in axial compression shows the concrete crushing at that point (Figure 6(a)). A relatively dense mesh was formulated at a maximum element size of $20 \mathrm{~mm}$ ( $0.4 \%$ of the specimen length). Boundary conditions were applied to simulate a simply-supported condition by constraining necessary nodes in translation at the supports of the specimens. The total number of elements is considered suitable after reaching appropriate convergence in numerical results. The standard Newton-Raphson method was used to solve nonlinear iterations.

\section{Comparison of numerical and experimental results}

The compressive load capacity and ultimate axial deflection of the composite columns calculated using the numerical model are summarized in Table 3 along with the ratio of numerical predictions to experimental results. From the table, it can be seen that, overall, the numerical predictions are in close agreement with the experimental results. The axial load versus deflection relationships for the tested composite columns obtained from the numerical model are shown in Figures 7 and 8 along with the experimental test results. The obtained load-deflection curves indicate that the curve corresponding to the monotonic test can be considered as the envelope of the curve of the cyclic test. Moreover, the envelope curve is an important parameter for a cyclic tested specimen. From these figures, it can be seen that the numerical predictions are in good agreement with the overall load-deflection behavior of the tested columns. Deviation of the numerical predictions from the experimental results can be attributed to the assumed stress-strain relationships for materials in the numerical model.

\subsection{Compressive load capacity}

The compressive load corresponding to an axial strain level is calculated by superimposing the separate con-

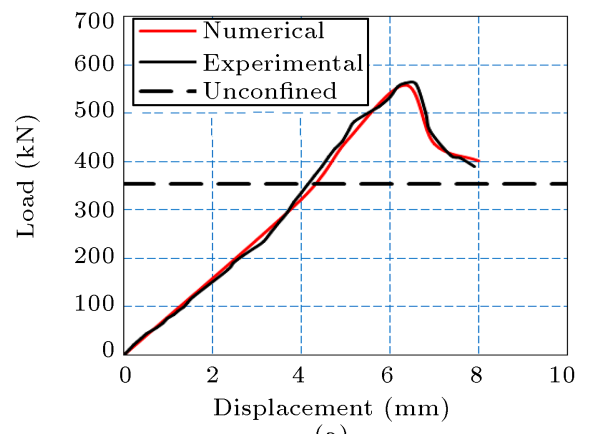

(a)

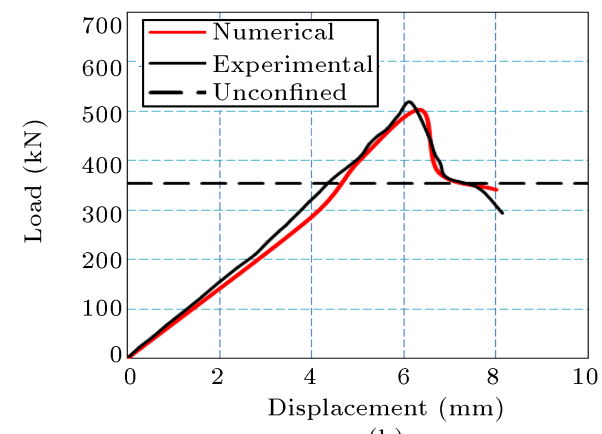

(b)

Figure 7. Comparison of the numerical and experimental load-deflection results (monotonic): (a) Fully confined column and (b) partially confined column. 


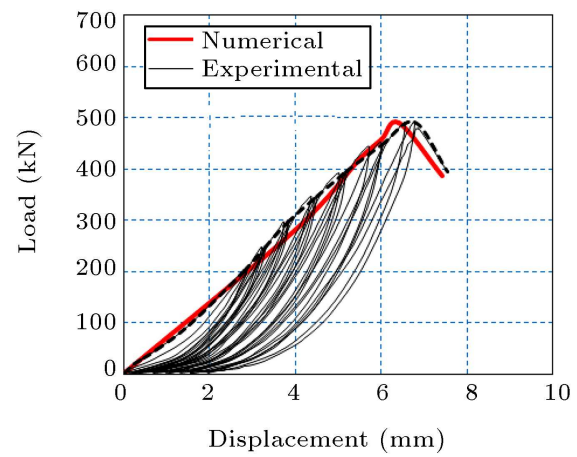

(a)

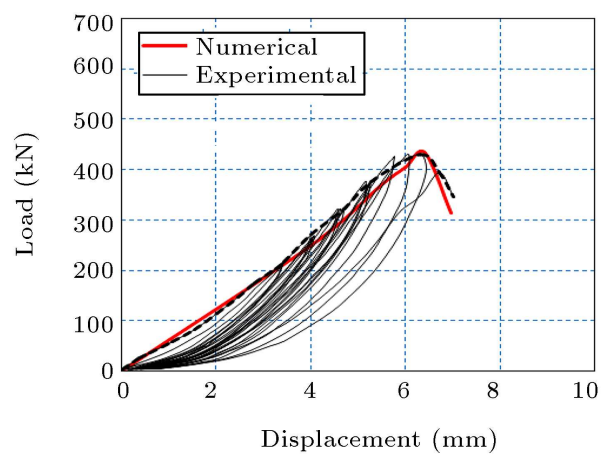

(b)

Figure 8. Comparison of the numerical and experimental load-deflection envelope curves (cyclic): (a) Fully confined column and (b) partially confined column.

tributions of the confined concrete, pultruded fiberglass I shape, and the CFRP layer on the load-carrying capacity given by:

$$
P=\sigma_{c} A_{c}+\sigma_{p} A_{p}+\sigma_{f} A_{f},
$$

where $\sigma_{c}, \sigma_{p}$, and $\sigma_{f}$ are the axial stress in the concrete, pultruded I shape, and the FRP layer, respectively, and $A_{c}, A_{p}$, and $A_{f}$ are their corresponding cross-section areas.

To evaluate the cross-section compressive load capacity, it is assumed that collapse occurs due to the failure of the pultruded fiberglass I shape and CFRP layer, resulting in loss of confinement. Rupture of the FRP can be assessed using the Tsai-Wu criterion, noninteractive maximum principal stress, and maximum principal strain criterion, among which Tsai-Wu criterion is commonly used for evaluating the failure of composite materials [61], given by:

$$
\begin{aligned}
A= & -\frac{\left(\sigma_{x}\right)^{2}}{\sigma_{x t}^{f} \sigma_{x c}^{f}}-\frac{\left(\sigma_{y}\right)^{2}}{\sigma_{y t}^{f} \sigma_{y c}^{f}}-\frac{\left(\sigma_{z}\right)^{2}}{\sigma_{z t}^{f} \sigma_{z c}^{f}}+\frac{\left(\sigma_{x y}\right)^{2}}{\left(\sigma_{x y}^{f}\right)^{2}} \\
& +\frac{\left(\sigma_{y z}\right)^{2}}{\left(\sigma_{y z}^{f}\right)^{2}}+\frac{\left(\sigma_{x z}\right)^{2}}{\left(\sigma_{x z}^{f}\right)^{2}}+\frac{C_{x y} \sigma_{x} \sigma_{y}}{\sqrt{\sigma_{x t} \sigma_{x c} \sigma_{y t} \sigma_{y c}}} \\
& +\frac{C_{y z} \sigma_{y} \sigma_{z}}{\sqrt{\sigma_{y t} \sigma_{y c} \sigma_{z t} \sigma_{z c}}}+\frac{C_{x z} \sigma_{x} \sigma_{z}}{\sqrt{\sigma_{x t} \sigma_{x c} \sigma_{z t} \sigma_{z c}}}, \\
B= & \left(\frac{1}{\sigma_{x t}^{f}}+\frac{1}{\sigma_{x c}^{f}}\right) \sigma_{x}+\left(\frac{1}{\sigma_{y t}^{f}}+\frac{1}{\sigma_{y c}^{f}}\right) \sigma_{y} \\
& +\left(\frac{1}{\sigma_{z t}^{f}}+\frac{1}{\sigma_{z c}^{f}}\right) \sigma_{z},
\end{aligned}
$$

where $C_{x y}, C_{y z}, C_{x z}$ are coupling coefficients in $x y, y z$, and $x z$, respectively. These coefficients can be defined in composite materials concepts $[61,62]$. The failure index $\xi_{3}$ of the Tsai-Wu interactive criterion can be written in the form of "strength index":

$$
\xi_{3}=A+B
$$

or in the inverse form of the "strength ratio":

$$
\xi_{3}=1.0 /\left(-\frac{B}{A}+\sqrt{(B / 2 A)^{2}+1.0 / A}\right) .
$$

The applied criterion for compression concrete is Willam-Warnke [63]. Table 4 shows the progressive failure based on sequential material failures. For each composite column, the failure mechanism was evaluated at the ultimate (failure) load level.

\section{Effect of the strips along the depth of column}

Through the analysis of the FE of fully and partially wrapped composite columns whose CFRP strips are $100,75,50$, and $25 \mathrm{~mm}$ in width, it can be observed that for the proposed composite column, the strength of partially wrapped columns (three strips along the depth of a cylinder) increases with increase in the width of CFRP strips (see Table 5). However, it should be noted that compared to the full confinement system, the partial confinement arrangements are more inexpensive to apply.

\section{Effect of the CFRP strip width and layer number}

Through the analysis of the FE of partially wrapped composite columns with strip widths of $25,50,75$, and $100 \mathrm{~mm}$ and the layer numbers of 1, 2, 3, and 4 , it can be observed that the strength and stiffness of the composite column increased with increase in the number of layers (see Figures 9 and 10). Moreover, according to this figure, the positive effect of the strip width on the load-bearing capacity of the column is significant. 
Table 4. Failure index and mode of failure of composite columns at the failure load.

\begin{tabular}{|c|c|c|c|c|c|c|c|c|}
\hline \multirow{3}{*}{$\begin{array}{l}\text { Column } \\
\text { design }\end{array}$} & \multirow{3}{*}{$\begin{array}{c}\text { Applied } \\
\text { load } \\
(\mathrm{kN})\end{array}$} & \multirow{3}{*}{$\begin{array}{c}\text { Strip } \\
\text { with } \\
(\mathrm{mm})\end{array}$} & \multicolumn{5}{|c|}{ Failure index } & \multirow[b]{3}{*}{ M. O. F } \\
\hline & & & \multirow[b]{2}{*}{ Concrete } & \multicolumn{2}{|c|}{ Pultrusion } & \multicolumn{2}{|c|}{ CFRP Cylinder } & \\
\hline & & & & Max stress & Tsai-Wu & Max stress & Tsai-Wu & \\
\hline \multirow{4}{*}{$\begin{array}{c}\text { Partial CFRP } \\
\text { confinement }\end{array}$} & 341.31 & 100 & 1.23 & 0.65 & 0.66 & 1.22 & 1.33 & Debonding \\
\hline & 286.30 & 75 & 1.29 & 0.68 & 0.69 & 0.24 & 0.36 & Crushing concrete \\
\hline & 231.54 & 50 & 1.16 & 0.67 & 0.68 & 1.02 & 1.04 & CFRP layer rupture \\
\hline & 181.32 & 25 & 1.16 & 1.17 & 1.17 & 0.83 & 0.85 & Pultruded failure \\
\hline $\begin{array}{l}\text { Full CFRP } \\
\text { confinement }\end{array}$ & 400.13 & 500 & 1.13 & 0.63 & 0.64 & 1.21 & 1.30 & CFRP layer rupture \\
\hline
\end{tabular}

Table 5. Partially and confined composite columns with different amounts of the Carbon Fiber-Reinforced Polymer (CFRP).

\begin{tabular}{|c|c|c|c|c|c|c|c|c|c|c|}
\hline $\begin{array}{l}\text { Composite } \\
\text { column }\end{array}$ & $\begin{array}{c}\text { Cross } \\
\text { section } \\
\mathbf{L} \times \mathbf{D} \\
(\mathbf{m m})\end{array}$ & $\begin{array}{c}\text { Pultruded } \\
\text { I-shape } \\
d_{s} \times b_{f} \times t_{w} \times t_{f}\end{array}$ & $\begin{array}{l}\text { Strip } \\
\text { width } \\
(\mathrm{mm})\end{array}$ & $\begin{array}{l}\text { Loading } \\
\text { type }\end{array}$ & $\begin{array}{c}\text { Maximum } \\
\text { load } \\
(\mathrm{kN})\end{array}$ & $\begin{array}{c}\text { Maximum } \\
\text { displacement } \\
(\mathbf{m m})\end{array}$ & $\begin{array}{c}\text { Average } \\
\text { elastic } \\
\text { stiffness } \\
(\mathrm{kN} / \mathrm{mm})\end{array}$ & $\begin{array}{c}\text { Failure } \\
\text { load } \\
(\mathrm{kN})\end{array}$ & $\begin{array}{c}\text { Failure } \\
\text { displacement } \\
(\mathbf{m m})\end{array}$ & $\begin{array}{c}\text { Difference } \\
\text { in load } \\
\text { capacity }\end{array}$ \\
\hline \multirow{8}{*}{$\begin{array}{c}\text { Partial } \\
\text { CFRP } \\
\text { confinement }\end{array}$} & \multirow{8}{*}{$500 \times 108.8$} & \multirow{8}{*}{$40 \times 60 \times 5 \times 5$} & \multirow{2}{*}{25} & Monotonic & 338.3 & 6.378 & 48.149 & 181.3 & 7.5 & 0.67 \\
\hline & & & & Cyclic & 264.9 & 6.39 & 36.565 & 150.5 & 6.77 & 0.61 \\
\hline & & & \multirow{2}{*}{50} & Monotonic & 393.7 & 6.376 & 54.393 & 231.5 & 8.0 & 0.78 \\
\hline & & & & Cyclic & 322.0 & 6.42 & 45.258 & 201.8 & 6.84 & 0.74 \\
\hline & & & \multirow{2}{*}{75} & Monotonic & 445.0 & 6.374 & 64.607 & 286.3 & 8.0 & 0.89 \\
\hline & & & & Cyclic & 377.8 & 6.42 & 53.955 & 259.7 & 6.82 & 0.87 \\
\hline & & & \multirow{2}{*}{100} & Monotonic & 504.9 & 6.38 & 71.786 & 341.3 & 8.0 & 0 \\
\hline & & & & Cyclic & 433.7 & 6.42 & 62.651 & 314.5 & 6.97 & 0 \\
\hline \multirow{2}{*}{$\begin{array}{c}\text { Full } \\
\text { CFRP } \\
\text { confinement }\end{array}$} & \multirow{2}{*}{$500 \times 108.8$} & \multirow{2}{*}{$40 \times 60 \times 5 \times 5$} & \multirow[t]{2}{*}{500} & Monotonic & 557.7 & 6.35 & 80.482 & 400.1 & 8.0 & 1.1 \\
\hline & & & & Cyclic & 489.5 & 6.42 & 70.121 & 386.2 & 7.42 & 1.13 \\
\hline
\end{tabular}

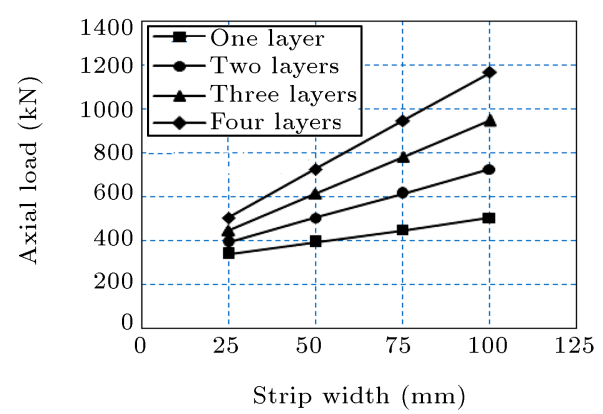

(a)

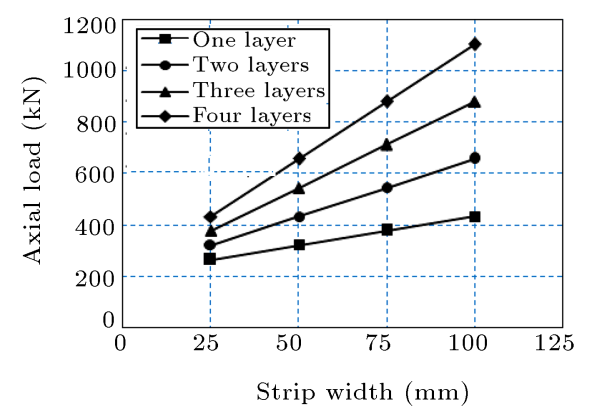

(b)

Figure 9. Comparison of load versus strip width relationships for different layer numbers: (a) Monotonic and (b) cyclic.

\section{Conclusion}

A novel composite column consisting of pultruded fiberglass I shape, concrete, and FRP wrapping (continuous and discrete confinement arrangements) was introduced, and these types of columns were tested under monotonic and cyclic compressive loading. Moreover, a numerical model was developed to predict the monotonic and cyclic compressive behavior of these com- posite columns. From this investigation, the following conclusions can be drawn:

1. External wrappings made of carbon fibre/epoxy and concrete used for encasing a structural FRP I shape not only increase their stiffness but also prevent local buckling failure and sudden rupture of the pultruded I sections;

2. To verify the numerical model, five composite 


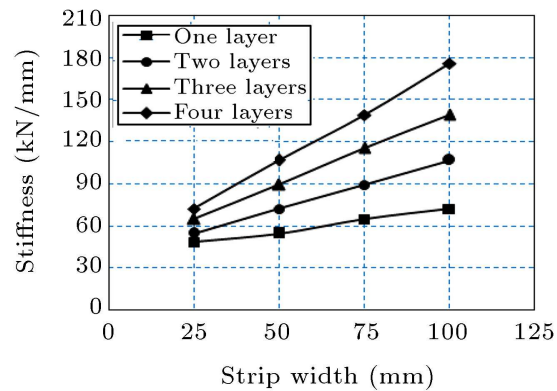

(a)

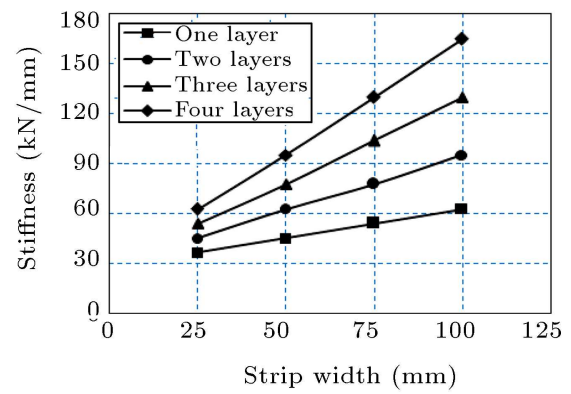

(b)

Figure 10. Comparison of stiffness versus strip width relationships for different layer numbers: (a) Monotonic and (b) cyclic.

columns were constructed and tested. The numerical model predictions were close to experimental results. In a wide range of the investigated loadbearing capacity values, less than $5 \%$ error was observed between the compressive strength predictions using the finite element analysis and the experimental results;

3. According to the results of the specimens, it was verified that the load-carrying capacity of partially confined specimens was slightly lower than that of the fully confined specimens. However, it should be kept in mind that partial confinement arrangements were more inexpensive to apply than full confinement arrangements. The obtained load-deflection curves indicate that the curve of the monotonic test can be considered as the envelope of the curve of the corresponding cyclic test;

4. Based on the failure mechanism in the numerical study, the ultimate loads (failure load) of 181.32, $231.54,286.3$, and $341.31 \mathrm{kN}$ for the Carbon FiberReinforced Polymer (CFRP) strips characterized by $25,50,75$, and $100 \mathrm{~mm}$ in width were obtained, respectively, which corresponded to the concrete crushing or FRP failure. In addition, the ultimate load of columns with CFRP layer (fully wrapped) was $400.13 \mathrm{kN}$ as a result of the failure mechanism;

5. The load-deflection curve of the partially wrapped columns is similar to the envelope of the fully wrapped columns. These load-deflection curves are divided into elastic, inelastic, and descending stages. The peak load increases with an increase in the compressive strength of concrete. Under the same conditions, the peak load of a partially confined column is lower than that of the corresponding fully confined column because the hoop tensile strength of the partially confined column is lower than that of the fully confined column;

6. The peak load of partially confined columns increased when the width of CFRP strips increased; however, the lower effectiveness (the load-carrying capacity and stiffness) of discrete confinement systems can be justified by the accumulated damage to the unconfined concrete in between the strips;

7. The numerical results indicated that the compressive load capacity and the stiffness of the columns increased with the increasing number of layers. In addition, the efficiency of CFRP wrap in confining composite columns increased significantly by increasing strip width.

\section{References}

1. Teng, J.G., Yu, T., Wong, Y.L., and Dong, S.L. "Hybrid FRP-concrete-steel tubular columns: concept and behavior", J Constr Build Mater, 21, pp. 846-854 (2007).

2. Ozbakkaloglu, T. and Oehlers, D.J. "Manufacture and testing of a novel FRP tube confinement system", Eng Struct, 30(9), pp. 2448-2459 (2008).

3. Mohamed, H.M. and Masmoudi, R. "Axial load capacity of concrete-filled FRP tube columns: experimental versus theoretical prediction", J Compos Constr, 14(2), pp. 231-243 (2010).

4. Dundar, C., Erturkmen, D., and Tokgoz, S. "Studies on carbon fiber polymer confined slender plain and steel fiber rein forced concrete columns", Eng. Struct, 102, pp. 31-39 (2015).

5. Youssf, O., ElGawady, M.A., and Mills, J.E. "Displacement and plastic hinge length of FRP confined circular reinforced concrete columns", Eng Struct, 101, pp. 465-476 (2015).

6. Choudhury, M.S.I., Amin, A.F.M.S., Islam, M.M., and Hasnat, A. "Effect of confining pressure distribution on the dilation behavior in FRP-confined plain concrete columns using stone, brick and recycled aggregates", Constr Build Mater, 102, pp. 541-551 (2016).

7. Davol, A., Burgueno, R., and Seible, F. "Flexural behavior of circular concrete filled FRP shells", $J$ Struct Eng, 127(7), pp. 810-817 (2001).

8. ElGawady, M.A., Booker, A.J., and Dawood, H.M. "Seismic behavior of post tensioned concrete-filled 
fiber tubes", J Compos Constr ASCE, 14(5), pp. 616$628(2010)$.

9. Yan, L. and Chou, N. "Compressive and flexural behaviour and theoretical analysis of flax fibre reinforced polymer tube encased coir fibre reinforced concrete composite", Mater Des, 52, pp. 801-811 (2013).

10. Abouzied, A. and Masmoudi, R. "Structural performance of new fully and partially concrete filled rectangular FRP-tube beams", Constr Build Mater, 101, pp. 652-660 (2015).

11. Huang, L., Sun, X., Yan, L., and Zhu, D. "Compressive behavior of concrete confined with GFRP tubes and steel spirals", Polymers, 7(5), pp. 851-875 (2015).

12. Xie, T. and Ozbakkaloglu, T. "Behavior of recycled aggregate concrete-filled basalt and carbon FRP tubes", Constr Build Mater, 105, pp. 132-143 (2016).

13. Shao, Y., Zhu, Z., and Mirmiran, A. "Cyclic modeling of FRP-confined concrete with improved ductility", Cement and Concrete Composites, 28(10), pp. 959968 (2006).

14. Varma, R.K., Barros, J.A.O., Sena-Cruz, J., and Ferreira, D.M. "A model to simulate the cyclic axial compressive behavior of RC columns confined with CFRP sheets", Portugal: CCC, University of Minho (2008).

15. Barros, J.A.O. and Ferreira, D.R.S.M. "Partial versus full wrapping confinement systems for concrete columns", International Conference on Concrete Repair. Rehabilitation and Retrofitting, South Africa, pp. 1123-1129 (2008).

16. Teng, J.G., Yu, T., Wong, Y.L., and Dong, S.L. "Hybrid FRP-concrete-steel tubular columns: concept and behavior", Constr Build Mater, 21(4), pp. 846854 (2007).

17. Lim, J.C. and Ozbakkaloglu, T. "Stress-strain model for normal- and light-weight concretes under uniaxial and triaxial compression", Constr Build Mater, 102, pp. 541-551 (2016).

18. Wong, Y.L., Yu, T., Teng, J.G., and Dong, S.L. "Behavior of FRP-confined concrete in annular section columns", Compos Part B, 38, pp. 451-466 (2008).

19. Yu, T. and Teng, J.G. "Behavior of hybrid FRPconcrete-steel double-skin tubular columns with a square outer tube and a circular inner tube subjected to axial compression", J Compos Constr ASCE, 17(2), pp. 271-279 (2013).

20. Fanggi, B.A.L. and Ozbakkaloglu, T. "Behavior of hollow and concrete-filled FRP-HSC and FRP-HSCsteel composites columns subjected to concentric compression", Adv Struct Eng, 18(5), pp. 715-738 (2015).

21. Fanggi, B.A.L. and Ozbakkaloglu, T. "Square FRPHSC-steel composite columns: behavior under axial compression", Eng Struct, 92, pp. 156-171 (2015).
22. Ozbakkaloglu, T. "A novel FRP-dual-grade concretesteel composite column system", Thin-Walled Struct, 96, pp. 295-306 (2015).

23. Ozbakkaloglu, T., Fanggi, B.A.L., and Zheng, J. "Confinement model for concrete in circular and square FRP-concrete-steel double-skin composite columns", Materials and Design, 96, pp. 458-469 (2016).

24. Ozbakkaloglu, T. and Fanggi, B.A.L. "FRP-HSC-steel double-skin tubular columns: behavior under monotonic and cyclic axial compression", Mater Struct, 48, pp. 1075-1093 (2015).

25. Yu, T., Zhang, B., Cao, Y.B., and Teng, J.G. "Behavior of hybrid FRP-concrete-steel double skin tubular columns subjected to cyclic axial compression", ThinWalled Structures, 61, pp. 196-203 (2012).

26. Han, L.H., Tao, Z., Liao, F.Y., and Xu, Y. "Tests on cyclic performance of FRP-concrete-steel double-skin tubular columns", Thin-Walled Struct, 48(6), pp. 430439 (2010).

27. Zhang, B., Teng, J.G., and Yu, T. "Experimental behavior of hybrid FRP-concrete-steel double-skin tubular columns under combined axial compression and cyclic lateral loading", Eng Struct, 99, pp. 214231 (2015).

28. Cui, C. and Sheikh, S.A. "Experimental study of normal-and high-strength concrete confined with fiberreinforced polymers", J Compos Constr, 14(5), pp. 553-561 (2010).

29. Xiao, QG., Teng, J.G., and Yu, T. "Behavior and modeling of confined high-strength concrete", J Compos Constr, 14(3), pp. 249-259 (2010).

30. Zohrevand, P. and Mirmiran, A. "Behavior of ultrahigh-performance concrete confined by fiberreinforced polymers", J Mater Civ Eng, 23(12), pp. 1727-1734 (2011).

31. Pham, T.M. and Hadi, M.N. "Confinement model for FRP confined normal-and high-strength concrete circular columns", Constr Build Mater, 69, pp. 83-90 (2014).

32. Ozbakkaloglu, T. "Axial compressive behavior of square and rectangular high-strength concrete-filled FRP tubes", J Compos Constr ASCE, 17(1), pp. 151161 (2013).

33. Idris, Y. and Ozbakkaloglu, T. "Seismic behavior of high-strength concrete-filled FRP tube columns", $J$ Compos Constr, 17(6), 04013013 (2013). https://doi.org/10.1061/(ASCE)CC.19435614.0000388

34. Ozbakkaloglu, T. "Behavior of square and rectangular ultra high-strength concrete-filled FRP tubes under axial compression", Compos B Eng, 54, pp. 97-111 (2013).

35. Nataraja, M.C., Dhang, N., and Gupta, A.P. "Stressstrain curves for steel-fiber reinforced concrete under compression", Cem Concr Compos, 21(5), pp. 383-390 (1999). 
36. Bhargava, P., Sharma, U.K., and Kaushik, S.K. "Compressive stress-strain behavior of small scale steel fibre reinforced high strength concrete cylinders", $J A d v$ Concr Technol, 4(1), pp. 109-121 (2006).

37. Chi, Y., Xu, L., and Zhang, Y. "Experimental study on hybrid fiber-reinforced concrete subjected to uniaxial compression", J Mater Civ Eng, 26(2), pp. 211-8 (2012).

38. Hassan, A.M.T., Jones, S.W., and Mahmud, G.H. "Experimental test methods to determine the uniaxial tensile and compressive behavior of ultra-high performance fibre reinforced concrete (UHPFRC)", Constr Build Mater, 37, pp. 874-882 (2012).

39. Caballero-Morrison, K.E., Bonet, J.L., NavarroGregori, J., and Serna-Ros, P. "An experimental study of steel fiber-reinforced high-strength concrete slender columns under cyclic loading", Eng Struct, 57, pp. 565-577 (2013).

40. Xie, T. and Ozbakkaloglu, T. "Behavior of steel fiber-reinforced high-strength concrete-filled FRP tube columns under axial compression", Eng Struct, 90, pp. 158-171 (2015).

41. Mandal, S., Hoskin, A., and Fam, A. "Influence of concrete strength on confinement effectiveness of fiberreinforced polymer circular jackets", ACI Struct J, 102(3), pp. 383-392 (2005).

42. Vincent, T. and Ozbakkaloglu, T. "Influence of concrete strength and confinement method on axial compressive behavior of FRP confined high-and ultra highstrength concrete", Compos B Eng, 50, pp. 413-428 (2013).

43. Wu, H.L., Wang, Y.F., Yu, L., and Li, X.R. "Experimental and computational studies on high strength concrete circular columns confined by aramid fiberreinforced polymer sheets", J Compos Constr, 13(2), pp. 125-134 (2009).

44. Li, G., Torres, S., Alaywan, W., and Abadie, C. "Experimental study of FRP tube-encased concrete columns", J Compos Mater, 39(13), pp. 1131-1145 (2005).

45. Vincent, T. and Ozbakkaloglu, T. "Influence of concrete strength and confinement method on axial compressive behavior of FRP confined high-and ultra highstrength concrete", Compos B Eng, 50, pp. 413-428 (2013).

46. Jian, C., Lim, T., and Ozbakkaloglu, T. "Stress-strain model for normal- and light-weight concretes under uniaxial and triaxial compression", Construction and Building Materials, 71, pp. 492-509 (2014).

47. Karimi, K., Tait, M.J., and El-Dakhakhni, W.W. "Testing and modeling of a novel FRP-encased steelconcrete composite column", J compos struct, 93(5), pp. 1463-1473 (2011).
48. Nanni, A., Fiber Reinforced Plastic (FRP) Reinforcement for Concrete Structures, Properties and Application, Amsterdam: Elsevier (1993).

49. Vitiello, E., Buccino, F., Cucchi, A., and De Salve, P.L. "Association of glass fiber reinforced plastic (GFRP) and concrete for a new type of slab", In: International Conference on New Technologies in Structural Engineering, Lisbon, Portugal, pp. 65-72 (1997).

50. Biddah, A. "Structural reinforcement of bridge decks using pultruded GFRP grating", J Compos Struct, $\mathbf{7 4 ,}$ pp. $80-88$ (2008).

51. He, J., Liu, Y., Chen, A., and Dai, L. "Experimental investigation of movable hybrid GFRP and concrete bridge deck", Constr Build Mater, 26, pp. 49-64 (2012).

52. Kim, Y.J. and Fam, A. "Numerical analysis of pultruded GFRP box girders supporting adhesivelybonded concrete deck in flexure", Eng Struct, 33, pp. 3527-3536 (2011).

53. Kabir, M.Z. and Eshaghian, M. "Flexural upgrading of steel-concrete composite girders using externally bonded CFRP reinforcement", Appl Compos Mater, 17, pp. 209-224 (2010).

54. Carey, S.A. and Harries, K.A. "Axial behavior and modeling of confined small-, medium-, and large-scale circular sections with carbon fiber-reinforced polymer jackets", ACI Struct J, 102(4), pp. 596-604 (2005).

55. Mourad, S.M. Sand hannag, M.J. "Repair and strengthening of reinforced concrete square columns using ferrocement jackets", Cement \& Concrete Composites, 34(2), pp. 288-294 (2012).

56. Ma, C.K., Awang, A.Z., and Omar, W. "Flexural ductility design of confined high-strength concrete columns", Theoretical modeling Measurement, 78, pp. 42-48 (2016).

57. Youm, K.S., Cho, J.Y., Lee, Y.H., and Kim, J.J. "Seismic performance of modular columns made of concrete filled FRP tubes", Engineering Structures, 57, pp. 37-50 (2013).

58. Shih, T.H., Chen, C.C., Weng, C.C., and Yin, S.Y.L. "Axial strength and ductility of square composite columns with two interlocking spirals", Journal of Constructional Steel Research, 90, pp. 184-192 (2013).

59. Barros, J.A.O., Ferreira, D.R.S.M., and Varma, R.K., CFRP-Confined Reinforced Concrete Elements Subjected to Cyclic Compressive Loading, Portugal: University of Minho, CCC (2008).

60. ANSYS, ANSYS online manual (12.1), Canonsburg, PA, USA (2014).

61. Tsai, S.W. and Wu, E.M. "A general theory of anisotropic materials", J Compos Mater, 5, pp. 58-80 (1971).

62. Jones, R.M., Mechanics of Composite Materials, Taylor \& Francis (1998).

63. Willam, K.J. and Warnke, E.D. "Constitutive model 
for the triaxial behavior of concrete", In: Proceedings of the International Association for Bridge and Structural Engineering, 19, pp. 1-30 (1975).

\section{Biographies}

Mohsen Ishaqian received his MS degree from Amirkabir University of Technology and his $\mathrm{PhD}$ degree in structural engineering from Amirkabir University of Technology, Tehran, Iran. His research interests include concrete structures, steel structures, structural stability, and structural analysis using FEM, experi- mental methods in structural engineering, composite structures, modeling, and rehabilitation of structural members using FRP materials.

Abolghassem Keramati is an Assistant Professor at the Civil and Environmental Engineering Department at Amirkabir University of Technology, Tehran, Iran. His research interests include structural concrete, structural stability, and structural analysis using FEM, experimental methods in structural engineering, composite structures, steel structures, damage detection, and rehabilitation of structures. 